\title{
Urdimento
}

Revista de Estudos em Artes Cênicas

E-ISSN: 2358.6958

\section{Dançarescrevendo corpografias de uma pandemia}

Neila Cristina Baldi

Oneide Alessandro Silva dos Santos

Daniela Minello

Cinara Neujahr dos Santos

\section{Para citar este artigo:}

BALDI, Neila Cristina; SANTOS, Oneide Alessandro Silva dos; MIBELLO, Daniela; SANTOS, Cinara Neujahr dos. Dançarescrevendo corpografias de uma pandemia. Urdimento, Florianópolis, v. 1, n. 40, mar./abr. 2021.

d. DOI: http:/dx.doi.org/10.5965/1414573101402021e0302

Este artigo passou pelo Plagiarism Detection Software | iThenticate 


\begin{abstract}
Resumo
Este artigo discute as ações do Grupo de Pesquisa sobre (Es)(ins)critas do/no Corpo (Corpografias) da Universidade Federal de Santa Maria no contexto pandêmico. Inicialmente, o grupo fez uma pausa nas atividades e voltou on-line, modificando o escopo das pesquisas - de procedimentos de aprenderensinar dança. Os(As) integrantes passaram a investigar modos de se mover e (sobre)viver na pandemia. As investigações se valeram de práticas sensíveis a partir de abordagens somáticas. o texto reflete sobre este processo e o quanto o mesmo foi importante para um movimento de cura, da saída da anestesia para o saber-sentir. Conclui que as práticas têm caráter estético e político e a investigação é uma partilha do sensível.
\end{abstract}

Palavras-chave: Dança. Pandemia. Práticas sensíveis.

${ }^{1}$ Doutora e Mestra em Artes Cênicas pela Universidade Federal da Bahia (UFBA). Graduada em Dança pela Universidade Anhembi Morumbi. Professora do Curso de Dança-Licenciatura da Universidade Federal de Santa Maria (UFSM). Coordenadora do Programa Institucional de Bolsas de Iniciação à Docência (PIBID)/Dança. neilabaldi@gmail.com

(9) http://lattes.cnpq.br/2745371733382115 $\quad$ (iD https://orcid.org/0000-0002-4431-4998

2 Artista-docente da Dança. Mestrando em Educação e Artes pelo PPGE-UFSM. Licenciado em Dança (2020) pela Universidade Federal de Santa Maria. Foi bolsista CNPq no Grupo de Pesquisa Corpografias da UFSM e bolsista CAPES - PIBID durante 2016 à 2019. Participou de 2018 a 2019 como membro titular do colegiado de Dança Licenciatura. Professor do Grupo Integração e Arte da Faculdade Metodista Centenário. Atualmente trabalha na Coordenadoria de Cultura e Arte da UFSM, na gestão cultural e artística do Centro de Convenções da mesma universidade. oneidealessandro@hotmail.com

(9) http://lattes.cnpq.br/4477459088768443 $\quad$ (iD https://orcid.org/0000-0003-0319-3269

${ }^{3}$ Graduação em Educação Física pela Universidade Federal de Santa Maria (1996), graduação em Artes Cênicas pela Universidade Federal de Santa Maria (2009), Especialização em Psicopedagogia pelas Universidades Franciscanas - UFN (2011), Mestrado em Educação pela Universidade Federal de Santa Maria (2006) e Doutorado em Educação pela Universidade Federal de Santa Maria (2018). Professora doutora formadora pelo PNAIC- Pacto Nacional pela Alfabetização na Idade Certa e pelo PROIPE- Programa de inovações pedagógicas. É professora no curso de Licenciatura em Pedagogia da AMF - Antônio Meneghetti Faculdade. Atualmente está fazendo seu pós doutorado na UFRGS. danielaminello@yahoo.com.br

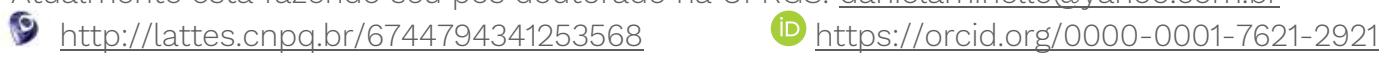

${ }^{4}$ Graduada em dança pela Universidade Federal de Santa Marina (UFSM). cineujahr@gmail.com

(9) http://lattes.cnpq.br/0145479355999208 3 (iD https://orcid.org/0000-0003-1305-6719 
Dance-writing pandemic corpographies

\begin{abstract}
This paper analyzes the research group's actions Writing/Inscrebed by/in the Body (Corpographies) of the Dance-Degree Course at the Federal University of Santa Maria (UFSM) in the pandemic context. Initially, the group suspended activities, but, later, returned online, changing the research scope to learning-teaching dance methods. The group's members started to investigate ways to move and live/survive during the pandemic. The research used sensitive practices, based on somatic approaches. The text reflects on this process and how important it was for a healing movement, from leaving stupor to the know-feel. We conclude that the practices have an aesthetic and political character and the research is a sharing of the sensitivity.
\end{abstract}

Keywords: Dance. Pandemic. Sensitive practices.

Bailandoescribiendo cuerrpografías en la pandemia

\begin{abstract}
Resumen
Este artículo analiza las acciones del Grupo de Investigación en (Es) (ins) escritos de / en el Cuerpo (Corpografías) de la Universidad Federal de Santa María en el contexto de la pandemia. Inicialmente, el grupo hizo una pausa en las actividades y regresó en línea, cambiando el alcance de la investigación, de los procedimientos a aprenderenseñar danza. Los miembros comenzaron a investigar formas de moverse y (sobre)vivir en la pandemia. Las investigaciones utilizaron prácticas sensibles basadas en enfoques somáticos. El texto reflexiona sobre este proceso y lo importante que fue para un movimiento de curación, desde dejar la anestesia hasta saber cómo sentirse. Se concluye que las prácticas tienen un carácter estético y político y la investigación es un compartir de lo sensible.
\end{abstract}

Palabras clave: Danza. Pandemia. Prácticas sensibles. 
O mundo parou. De repente, um vírus, invisível, fez todo mundo voltar para casa, isolar-se. Hospitais lotados. Corpos empilhados para serem incinerados. Caos sanitário. Cidades vazias. Distanciar-se seria sobreviver. Sozinhos(as) em casa, revendo nossas rotinas, sendo bombardeados(as) por notícias alarmantes mas reais. E então, como na canção de Oswaldo Montenegro (2014), nos vimos impelidos(as) a nos mover, pois: "Não sei se o poema é bonito. Mas sei que preciso escrever." Precisávamos escreverdançando, dançarescrevendo ${ }^{5}$, de forma a sobreviver àquilo tudo. Assim, nossas escritas - no papel e no movimento - nos possibilitaram estar aqui hoje, escrevendo este texto sobre os processos que vivenciamos em 2020, dentro do Grupo de Pesquisa sobre (Es)(ins)critas do/no Corpo (Corpografias), da Universidade Federal de Santa Maria, diante da pandemia da Covid-19 e da impossibilidade de nos encontrarmos presencialmente.

Estávamos no início do nosso processo - voltamos a nos reencontrar, entre-telas, em junho - como Clarice Lispector (1974, p. 129):

Sei - por meu próprio e único testemunho - que no início desse meu trabalho de procura eu não tinha a mais fraca ideia da espécie de linguagem que me seria revelada aos poucos até que eu pudesse um dia chegar a Constantinopla.

Não sabíamos o que fazer, não sabíamos como retomar nossas pesquisas vínhamos, no ano anterior, criando e testando procedimentos de aprenderensinar ${ }^{6}$ dança a partir da Autobiografia, Decolonialidade e Educação Somática. Criávamos e testávamos conosco e, depois, em espaços diversos - escolas, ONGs, oficinas etc. Como continuar sem a presencialidade? Como continuar no entre-telas ${ }^{7}$ ?

${ }^{5}$ Nos apoiamos em Fernandes (2013, p. 20), que pergunta: Como escrever uma dissertação e/ou uma tese no campo da dança, sendo coerente com a(s) dança(s), isto é, escreverdançando ou dançarescrevendo como atos de igual valor, constituição e consistência?

${ }^{6}$ Paulo Freire (1996, p. 24) diz que: "Aprender precedeu o ensinar ou, em outras palavras, ensinar se diluía na experiência realmente fundante de aprender." Como os dois verbos têm uma relação direta com o outro, proponho, apoiada em autoras da Pedagogia, como Carmen Lúcia Pérez e Carmen Sanches Sampaio (2012), o aprenderensinar juntos.

7 Temos chamado de entre-telas e não de telas, pois são múltiplos os dispositivos usados, muitas vezes estamos utilizando mais de uma tela - reunião pelo Zoom ou Google Meeting, pelo computador, e filmagem pelo celular; e também porque consideramos que a relação se dá entre as telas. 
Ciane Fernandes (2011, p. 89) diz que:

No contexto contemporâneo ameaçador, invasivo e incontrolável, a paragem - entendida como pausa dinâmica - restabelece a estabilidade do sujeito, possibilitando uma interação real baseada numa presença fluida. Estável é diferente de estático. É através da paragem que, paradoxalmente, o sujeito resiste ao movimento externo extremo e ativa o movimento interno intenso. Assim, a pausa ou paragem é intrinsecamente dinâmica, em fluxo.

Paramos numa pausa dinâmica, para nos reestabelecermos. E foi a volta ao movimento, por meio de práticas sensíveis de abordagens somáticas, realizadas de maneira síncrona, online, que nos refizemos, uma vez que, como afirma Fernandes (2011, p. 90): “Cientes do poder da pausa, muitas técnicas corporais utilizam-na como parte fundamental de seus ensinamentos. A pausa como exercício consciente pode ser encontrada em quase todas as técnicas de Educação Somática [...]."

Esta escritadançante ${ }^{8}$ tenta discutir e refletir sobre esse momento pandêmico, e como nossos dançaresescreventes e escriturasdançadas nos possibilitaram passar pela pandemia e nos refazer. E colocar no movimento - e no papel - nossas corpografias, aqui entendidas como tudo o que está inscrito/escrito no corpo ${ }^{9}$.

\section{Medos e desejos}

Nossas primeiras investigações vieram de uma pergunta, a partir de ítalo Calvino (1990, p. 44):

[...] tudo o que pode ser imaginado pode ser sonhado, mas mesmo o mais inesperado dos sonhos é um quebra-cabeça que esconde um desejo, ou então o seu oposto, o medo. [...] De uma cidade, não aproveitamos as

\footnotetext{
${ }^{8} \mathrm{O}$ Grupo de Pesquisa Corpografias tem assumido nas suas investigações a união de determinadas palavras, propondo um anelo artístico-científico delas a partir de Fernandes (2013). Procurando com isso uma melhor compreensão das relações entre teoria e prática - dança e escrita. Por isso, escritadançante, dançarescrevente e escrituradançada.
}

${ }^{9}$ Corpo compreendido como soma, sem separação corpo-mente. 
suas sete ou setenta e sete maravilhas, mas a resposta que dá às nossas perguntas.

Quais eram os nossos medos e desejos e quais respostas damos a este momento pandêmico? Começamos, então, a investigar em nossas cadeiras e durante a nossa pesquisa passamos a registrar o movimento em vídeo e em papel - o que do que vivíamos reverberava, o que era preciso transcrever, escrever em letras, números ou desenhos, nesta outra materialidade? Pegar o papel e a caneta ou lápis e durante o movimento - ou em uma pausa dinâmica - escrever o que se passa naquele momento. O neurocientista Miguel Nicolelis explica esta relação somática da mão com o papel:

Tudo o que eu começo a fazer começa na mão, com caneta tinteiro. Mas por quê? Porque pratica essa interação corpo-mente. A caligrafia, os chineses sabem disso há 6 mil anos, é um exercício humanístico extremamente potente, de manifestação humana, artística, de equilíbrio do que você pensa e como você move o seu corpo em relação ao pensamento.

$[\ldots]$

Para o meu novo livro, eu estudei um pouco sobre a descrição dos grandes pintores no momento em que eles encontraram o meio de pintura que usariam para o resto da vida. É o Picasso descrevendo a experiência dele de pegar na tinta, não pintar, mas sentir tatilmente a consistência da tinta óleo, do pastel óleo, que depois ele criou, o "sennelier", que a gente usa até hoje. E, à medida em que você começa a pintar - e eu aprendi depois de adulto e não parei mais -, você entende a lógica disso. Porque pintar não é só a arte de criar. É a arte de sentir a tinta, sentir a experiência tátil. E isso você não faz. Se você faz isso num tablet, como hoje a maioria das crianças faz, é muito diferente de você fazer analogicamente, metendo seus dedos na tinta (Nicolelis, 2020, s/n).

Todas as demais investigações - na cadeira ou fora dela, pois à medida que a pandemia avançava fomos explorando outros espaços em nossas casas tinham como tônica as práticas sensíveis e escritasdançantes. E todas nossas escritas - no espaço ou no papel - fazem parte desta pesquisa, pois como Fernandes (2013, p. 20) pergunta como é escrever sendo “[...] coerente com a(s) dança(s), isto é, escreverdançando ou dançarescrevendo como atos de igual valor, constituição e consistência?” A escrita - no papel e no movimento - como cura. 
A escrita no papel como potência para o movimento. O movimento interferindo na escrita no papel. "Não se trata de escrever sobre, mas de escrever na. Escrever na experiência” (Ribetto, 2016, p. 59). Trata-se de uma escrita das necessidades e impulsos. Não necessariamente linear, podendo ser aos pedaços, fragmentada. A escrita no papel como rastros do movimento, de uma imagética dos sentidos (como na imagem abaixo, Figura 1):

Figura 1 - Reprodução de anotações durante a prática

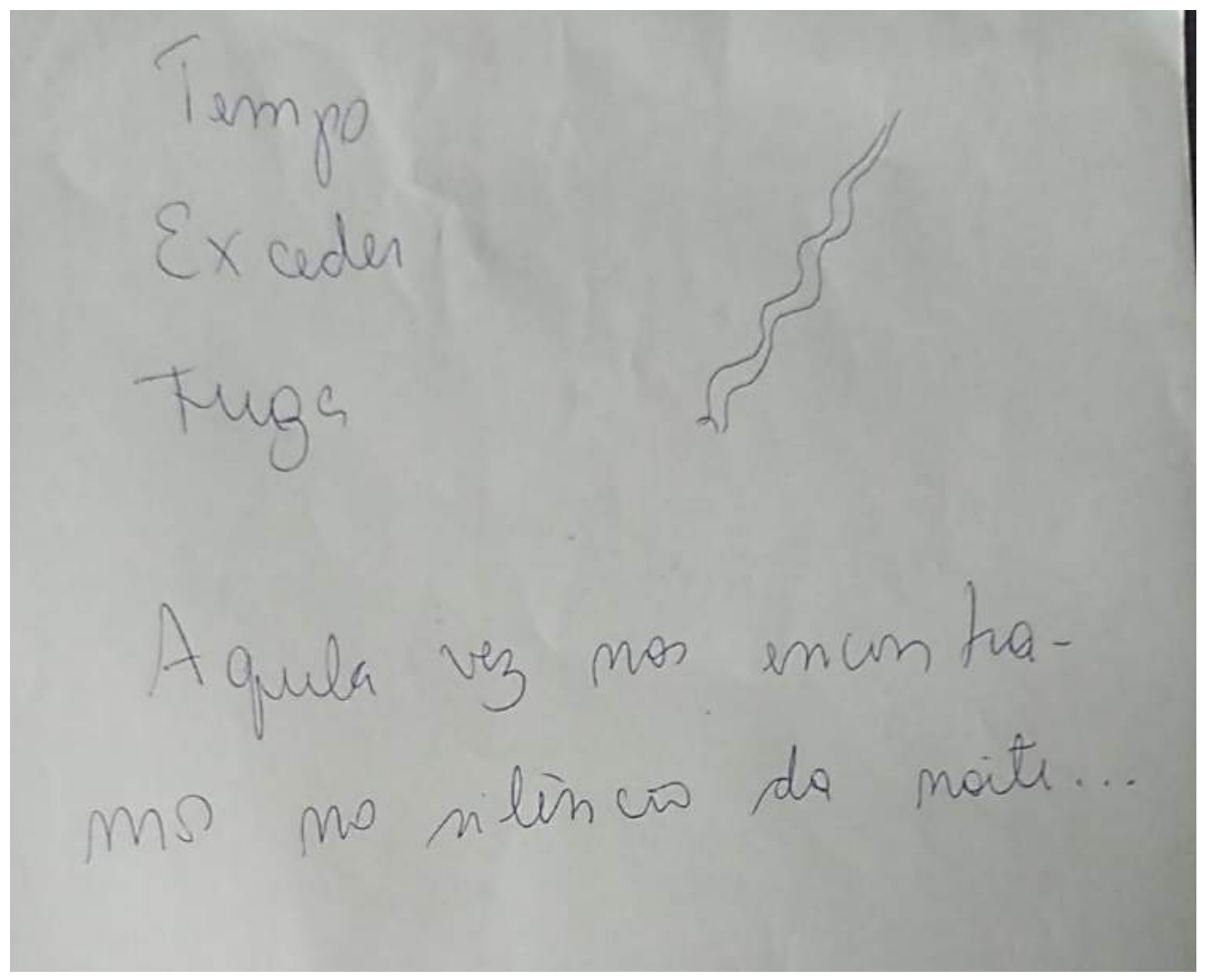

Fonte: Autores(as)

Palavras fugidias, como o movimento efêmero. Quando não gravamos/filmamos o que experimentamos, como revisitamos? O que nos dizem os papeis anotados? Palavras ao vento? Palavras-dançadas. Palavras que nos dizem do momento presente e nos lembram das investigações anteriores, como as anotações acima (Figura 1) em que nos remete ao nosso primeiro encontro com práticas sensíveis, que ocorreu numa noite. O ambiente interfere no nosso fazer, 
pois como nos lembra Thomas Hanna (1976), há um movimento interrelacional entre consciência, função biológica e meio ambiente, evidenciando a experimentação do mundo interior como integração sensorial.

No meio do turbilhão da pandemia, trouxemos o trabalho para nossas casas e, com ele, uma reconfiguração dos nossos lares e nossas rotinas. Passamos a ficar mais tempo sentados(as), em frente às telas - do computador ou do celular - trabalhando ou estudando, sem nos desligarmos e deixarmos de lado as demandas da casa - refeições, limpeza e cuidados com outros(as) - nos sobrecarregando de tarefas, ao mesmo tempo em que nossas ações são fragmentadas, porque precisam ser interrompidas diversas vezes pelas contingências do lar. Por outro lado, nossos lazeres também foram cancelados ou modificados - durante boa parte da pandemia não podíamos nem ir a parques, por exemplo - fazendo com que as telas - dos celulares, computadores ou televisões - também fossem nossos momentos de diversão, com filmes, lives de artistas, etc. Como dizem Jussara Miller e Cora Miller Laszlo (2020, p. 100):

Paradoxalmente, o movimento das informações enquadradas nas telas nos capturam, nos enquadram e nos paralisam diante do fluxo vertiginoso de informações da rede, gerando uma sobreposição do uso do tempo livre e do tempo de trabalho, ambos com a permanência do corpo sentado e conectado.

Diante disso, às vezes no silêncio da noite - quando os(as) demais ocupantes da casa estão dormindo ou, para os(as) que vivem sós, os(as) vizinhos(as) e o entorno já não são tão barulhentos, fica mais fácil parar e prestar atenção a si. Quando paro e escuto, o que o corpo fala? Quando encontro movimento na pausa? Mas, por outro lado, como é se conectar a si no meio do turbilhão, sem perder o entorno? Como é perceber a interferência do entorno e deixá-la fluir no movimento? Dançar com a gata passando entre as pernas, estar deitado(a) no chão e o cachorro dar uma lambida, ouvir sua respiração ao mesmo tempo em que ouve o choro do bebê? Como tudo isso nos afeta, como cria corpografias dançantes? 
Ao longo do ano passado - mais especificamente, a partir de junho, quando voltamos a nos reencontrar pelas telas, estas questões permearam nossas pesquisas e se desdobraram em movimentos no papel e no espaço. Culminaram com um processo criativo, que chamamos de experimento-obra corpos em Tempos de Espera10, mas seguiram depois dele, compreendendo que mais importante que produtos artísticos, neste momento pandêmico, era passar por esses processos de escuta de si e do(a) outro(a), de práticas sensíveis, de criações e improvisações individuais e coletivas.

\section{DesConstruíndo corpos e espaços entre formas}

Que corpo é esse que nos aprisiona? Que corpo é esse que nos permite a liberdade? Que corpo é esse que fala? Que corpo é esse que movimenta e/ou paralisa? Que corpo é esse? Em tempos de pandemia, estamos presos(as) ou nunca estivemos tão livres em outros espaços que antes não nos percebíamos? Pensar possibilidades de um corpo movente, de um corpo pensante, de um corpo atuante e de um corpo restrito é que fazemos tais questionamentos. Afinal:

O corpo nos reserva um grande número de meticulosas conexões, conscientes e/ou inconscientes, afloradas ou não, voluntárias ou não, que nos conduzem através das experiências vividas para sinopses ininterruptas de apropriações cognitivas e afetivas (Cunha, 2016, p. 234).

Como num movimento de catavento (ver Figura 2), em que quatro peças buscam movimentar-se em conjunto para gerar e liberar energia, assim fomos nos construindo e reconstruindo possibilidades dançantes para pensarmos e percorrermos caminhos singulares com possibilidades plurais.

10 Obra e experimento apresentado na 35 Jornada Acadêmica Integrada da Universidade Federal de Santa Maria em outubro de 2020 e no XIII Seminário Internacional de Pesquisa em Dança da Universidade Federal do Pará em novembro de 2020. 
Figura 2 - Reprodução de anotações de encontro de discussão do grupo

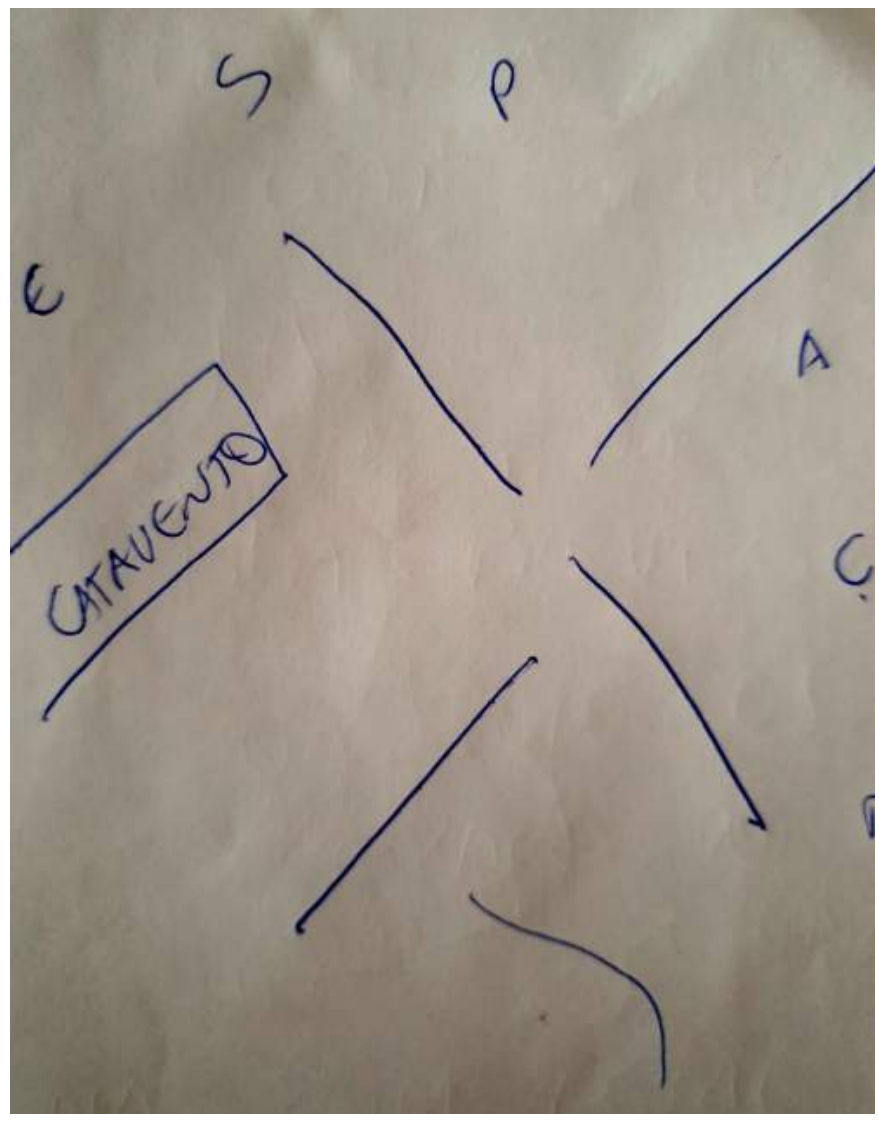

Fonte: Autores(as)

Pensar em um corpo que transita por espaços internos e externos mesmo estando aprisionados(as) aos nossos limites de ir e vir e às nossas consciências. O que fizemos da nossa liberdade vigiada e não mais permitida aos macro-espaços? Assim, entre espaços condensados e tensões corporais, fomos criando em nossos corpos marcas de medo e de não certezas sobre o tempo que viria, deixando de viver o tempo presente, o que realmente nos importava. Foi preciso parar. Nesta pausa, encontramos na respiração, a escuta do que precisávamos no momento. E, depois, compreendemos que a volta significava, também, uma respiração coletiva (Rachel, Marques, Mariano, 2020).

O grupo foi estabelecendo relações de escuta e colaboração coletiva, potencializando palavras, rabiscos e escritas de outras possibilidades que dançaram por entre papéis e espaços outros de pensar corpos reais em encontros 
virtuais, priorizando o que era mais urgente em nossos espaços/tempos de criações. Escritas individuais - no papel e no espaço - com cada um(a) na sua casa, na sua intimidade - mas também coletivas, em dimensões diversas. Coletivas porque dançávamos e escrevíamos juntos(as) - no espaço e no papel, mas também porque, como nos lembra Jorge Larrosa (2006, p. 25), "toda escritura pessoal, enquanto escritura, contém vestígios das palavras e histórias recebidas".

Passamos a desconstruir nossos modos de pensar sobre o que poderíamos produzir nos processos de criação em dança. Cada encontro era norteado pela pergunta: como vocês estão? A partir da escuta de si e do(a) outro(a) fomos elencando possibilidades para uma dança do aqui e agora com o que cada um(a) poderia e conseguiria. O processo criativo foi percorrendo caminhos diversificados em que dialogávamos entre curvas (Figura 3) e obstáculos que por muitas vezes nos paralisavam e mesmo assim eram utilizados como recurso para pensar um corpo que dança em espera e por vezes em fluxos contínuos. Nossos corpos passaram a dialogar por entre-telas e escritas que esboçavam fragmentos de nossas vidas cotidianas. Muitas vezes não conseguíamos nos mover e, assim, parávamos, respirávamos e nos escutávamos por entre telas compartilhadas, dialogando sobre caminhos que nos permitissem sair deste espaço de aprisionamento que sentimentos como medo e incertezas nos acometiam. 
Figura 3 - Reprodução de anotações de encontro de discussão do grupo

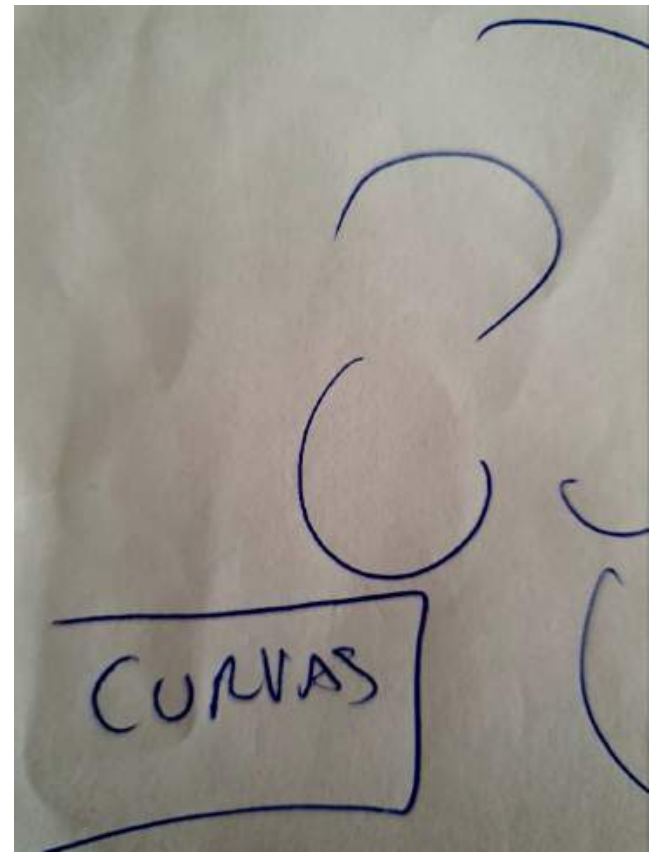

Fonte: Autores(as)

A cada proposta sugerida pelos(as) integrantes do grupo, era perceptível a urgência do cuidado de si e da escuta sobre tudo o que era mais relevante entre corpos dançantes que encontravam no coletivo uma motivação para seguir em frente. Márcia Araújo (2020, p. 407) diz que:

Experiências criativas vividas no corpo por meio de abordagens sensíveis, que respeitem um tempo próprio, ou seja, o tempo naturalmente afinado e viável para a construção de um saber sobre nós mesmos, têm sido frequentemente suprimidas diante do imperativo da vida moderna. É exatamente para criar espaçotempo e escuta significativos para uma formação sensível, que respeite as diferenças, expanda as formas de convivência e crie novas formas de diálogos, que propostas de manutenção da sensibilidade através das Artes tornam-se necessárias e fundamentais nos processos educacionais.

A vida contemporânea, regulada pelo tempo veloz da internet, muitas vezes não nos abre espaço para esta escuta - principalmente para aqueles(as) que não trabalham com Arte, Educação Somática ou terapias holísticas. A pandemia, que 
nos prendeu em frente às telas, como discutiremos mais à frente, pode favorecer anestesias. Abrir-se para a escuta de si e do(a) outro(a) é imperativo, sobretudo no momento atual, pandêmico, em um país em que milhares de pessoas morrem por falta de leitos, por ignorância e ideologias em relação ao vírus. Vivemos em um país adoecido e com falta de empatia. Assim, nossos momentos juntos(as) são refrescos para nós, são curas coletivas e individuais.

Neste processo, por vezes fomos produzindo redemoinhos que fortaleceram nossos encontros que tinham em comum o desejo pelos encontros presenciais para produzir pesquisa em dança. Tais redemoinhos (ver Figura 4, abaixo) ampliaram nossas compreensões sobre o que nos movia a pensar dança em tempos de pandemia. Por vários momentos pensávamos que avançar na pesquisa era o essencial, sendo que percebíamos que entre pausas encontrávamos potências que antes não nos permitíamos como um aspecto a encontrarmos nossas singularidades e as sutilezas dos diferentes olhares entre composições a partir de palavras disparadoras de ações. As vezes o não avançar foi nos permitindo este olhar e esta escuta de si e do grupo, promovendo ações que foram sendo transcritas por entre rabiscos no espaço do papel.

Figura 4 - Reprodução de anotações de encontro de discussão do grupo.

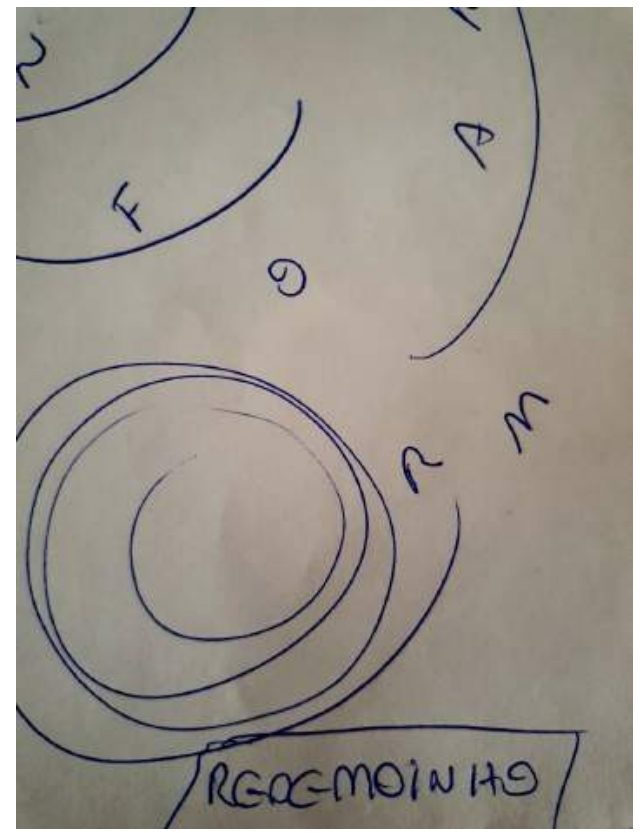

Fonte: Autores(as) 


\section{Faltam-nos palavras}

Fique em casa. Fique em casa. Fique em casa. Ou, a depender da região do país: Fica em casa, fica em casa, fica em casa - para quem usa você ou tu, respectivamente. Como um mantra ouvíamos e repetíamos isso no início da pandemia, quando todas as cidades do país começaram a fazer quarentenas, com redução da circulação das pessoas e das atividades econômicas. E, se precisávamos sair, usar máscara e álcool gel.

Casa. Máscara. Álcool gel. Casa. Máscara. Álcool gel. Casa. Máscara. Álcool gel. Casa. Máscara. Álcool gel. Casa. Máscara. Álcool gel. Sentíamos sufocados(as) pela rotina, por estar em casa, sem poder sair para a rua, com o risco da doença. E, então, na nossa primeira prática sensível - realizada quase um mês depois de voltarmos a nos encontrar no entre-telas, pois sentíamos paralisados(as), com dificuldade de sairmos para o movimento - recorremos a todas as palavras possíveis: escritas, faladas, desenhadas, dançadas. Depois compreendemos este momento não como uma paralisia, mas como uma pausa dinâmica, constituída de muito movimento interno e, como Clarice Lispector (1980, p. 29) de que: "Há muita coisa a dizer que não sei como dizer. Faltam-me as palavras. [...]." Então, o movimento, que começou contido, jorrou, transbordando as telas, o espaço, os papeis. Precisávamos falar, dançar, escrever, viver, sobreviver... e nossas escritas nos dizem disso (ver Figura 5). 
Figura 5: Reprodução de anotações durante a prática

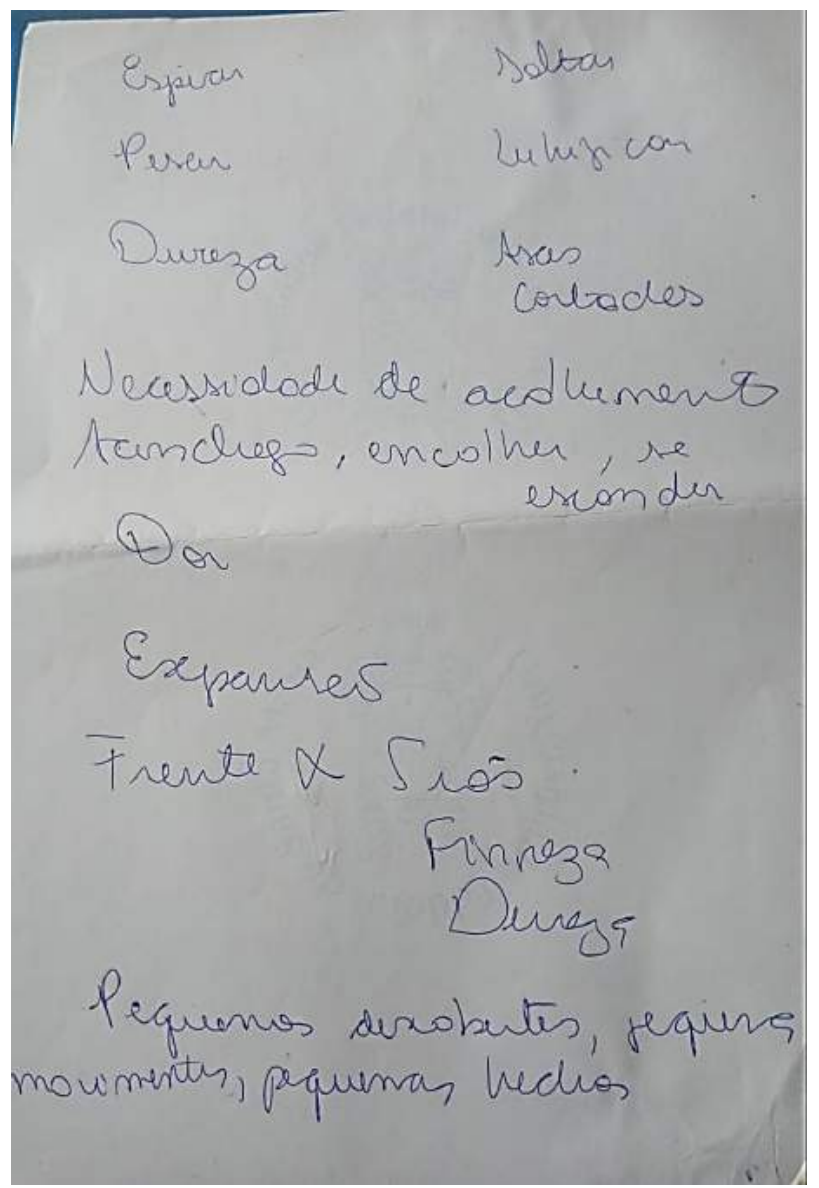

Fonte: Autores(as)

Anelice Ribetto (2009, p. 8) diz que: "Eles, os escritos, são movimentos do pensamento como pesquisa, da escritura como pensamento, da escritura como acontecimento, como padecimento." Nossas primeiras grafias demoraram a sair, mas aos poucos íamos nos movimentando, em micros movimentos, em micro escritas, e estas movimentações iniciais reverberaram nos dias seguintes, jorrando movimentos, danças.

A partir e com a prática sensível, escrevemos também no papel sobre nossas sensações, como nos sentíamos antes, durante e depois. Nossas anotações/percepções relatavam um corpo latente, com partes tensas pela falta de movimento durante a quarentena, pela rotina imposta pela pandemia em nossas casas, pelas nossas tensões emocionais. Conseguimos aos poucos dar 
atenção a essas demandas corporais, dando vazão a elas pela escrita - em movimento e no papel, que nos trouxeram um pouco de alívio às nossas preocupações, percebemos um novo caminho a seguir e investigar sem que nos exigíssemos em demasiado e acabássemos nos sobrecarregando ainda mais. 0 alívio entrou em fluxo e perpassou para o resto do corpo, trazendo mais tranquilidade, por termos tido esta gentileza conosco - cada um(a) consigo e com o(a) outro(a) - e em saber nos escutar, escutar nossos corpos, termos nos ouvido como grupo.

Além dessas notas sobre a prática sensível, escrevemos palavras-chaves para o momento, como: tensão, incômodo, ansiedade, escuta, relaxamento, etc. Alguns(Algumas) de nós criaram sequências coreográficas no mesmo dia desta primeira prática sensível, após a escrita, estudando movimentos, permitindo fluir através do corpo os sentimentos descritos. Outros(as) se permitiram um espaço de tempo entre a prática sensível e criação, e as revisitaram em outro momento para criar... Seguimos o mesmo pensamento, de escuta das necessidades de cada um(a) para produzir, não por uma falta de compromisso com a pesquisa, mas sim pelo respeito do tempo de cada naquele momento.

A partir das primeiras investigações acabamos produzindo o experimento criativo e obra Corpos em Tempos de Espera. Cada um(a) em sua casa, como os rastros das práticas sensíveis, ao seu modo, investigou as reverberações e filmou - de uma vez, como num gole, ou várias vezes, escolhendo aquele registro que melhor falasse o que sentia naquele momento. Cada um(a) acessou seu Mundo do Silêncio'11 (Laban, 1978) - memórias motoras e experiências corporais vivenciadas cotidianamente por uma pessoa. Como dizia Laban (1978, p. 156), “[...] esse mundo demasiado profundo para poder ser expresso, o mundo silencioso das ações simbólicas [...] resposta a uma necessidade interior do homem”. Ou, como explica Marcílio Vieira (2017, p. 47):

\footnotetext{
${ }^{11}$ O Mundo do Silêncio é um conceito complexo que envolve vários estudos de Laban, abrangendo as memórias motoras e experiências corporais, que podem ser desveladas em micro-movimentos ou movimentos de sombra, é [...] um silêncio a partir do qual tudo pode ser dito, a partir do qual tudo pode surgir" (Barbosa, 2016, p. 100). Aparece pela primeira vez em Domínio do Movimento (Laban, 1978).
} 
[...] Mundo do Silêncio seria um lugar hipotético que permitiria o homem ser capaz de produzir inúmeras variações e criações gestuais. Assim, para Laban o gesto humano não é apenas uma ação muscular, mas é um lugar de invenção e deriva e que se constitui no tempo em cada cultura. Por Mundo do Silêncio entende-se ainda, como pré-gesto, energias puras; é a alma humana em sua visão materialista, logo essa alma é efeito dos fazeres e gestos cotidianos e não uma entidade metafisica, logo, a natureza do gesto seria uma natureza de forças, de potências puras $\left(\right.$ Laban, 1978) ${ }^{12}$.

[...] Os gestos enfatizam, descrevem, completam; às vezes traem o conteúdo de um discurso oral. Os gestos fazem parte dos meios usados para o ser humano se comunicar; contribuem para dar forma e codificar as relações sociais entre os indivíduos e entre os grupos. Schmitt (2006) afirma serem os gestos constituintes de uma realidade social e que dependem da história social. São o meio pelo qual o corpo estabelece relações simbólicas enquanto apreensão individual, interpessoal e de movimento.

Tínhamos necessidade de falar do momento pandêmico. Falar por gestos, por movimentos, por escritas no papel, pela voz e acabamos por escrever, todos(as), juntos(as), em um dos nossos encontros on-line, um poema-manifesto dançante - que foi gravado em áudio e usado em uma das versões de edições da obra-experimento (abaixo) que fizemos ao longa das investigações:

Demos um tempo. Um tempo para a vida lá fora. E ficamos presos a um tempo expandido, que nunca acaba. Somos seres atemporais. Somos seres atemporais? Na pausa da vida lá fora, tem muita vida aqui dentro. Dentro de onde? Estamos em uma espera constante, sem saber quanto tempo ainda temos. Tempos de espera. Presos ao tempo, dentro de casa, presos às cadeiras. A cadeira como potência. O que é possível fazer em uma cadeira? Quanto menor o espaço, maior a necessidade do respiro. Eu consigo sair daqui? Como lidar com a inércia em meio à necessidade de nos mover? O tempo passa e precisamos lidar com o inesperado. O tempo passa e fica cada vez mais claro que precisamos nos reconstruir. Quanto tempo precisaremos para nos mover?

Em um dos nossos encontros, quando tínhamos escolhido uma versão editada da nossa obra-experimento do início das nossas investigações na pandemia - pois depois continuamos com nossas práticas sensíveis sem necessariamente gravarmos nossas investigações em vídeo, mas com ênfase nos registros no papel, com escritas de frases, rabiscos ou desenhos, compreendendo,

12 Na citação de Vieira (2017) há uma citação indireta a Laban (1978). 
como Rosemarie Anderson (2002, p. 41), que, "ao escrever a partir dessa perspectiva do corpo, o escritor (ou investigador) registra, por escrito, as formas sutis que o corpo responde à experiência e imbui sua escrita com a rica textura sensorial dessa experiência"13 - discutimos a feitura daquela obra, a partir de imagens de figuras geométricas que nos ocorriam, como um ventilador de várias pás, que cada uma dá suporte à outra ou como um lego, que uma peça se encaixa na outra e compõe um caleidoscópio de imagens e sensações (Ver Figuras 6 e 7, abaixo):

Figura 6 - Reprodução de frame do vídeo Corpos em Tempos de Espera

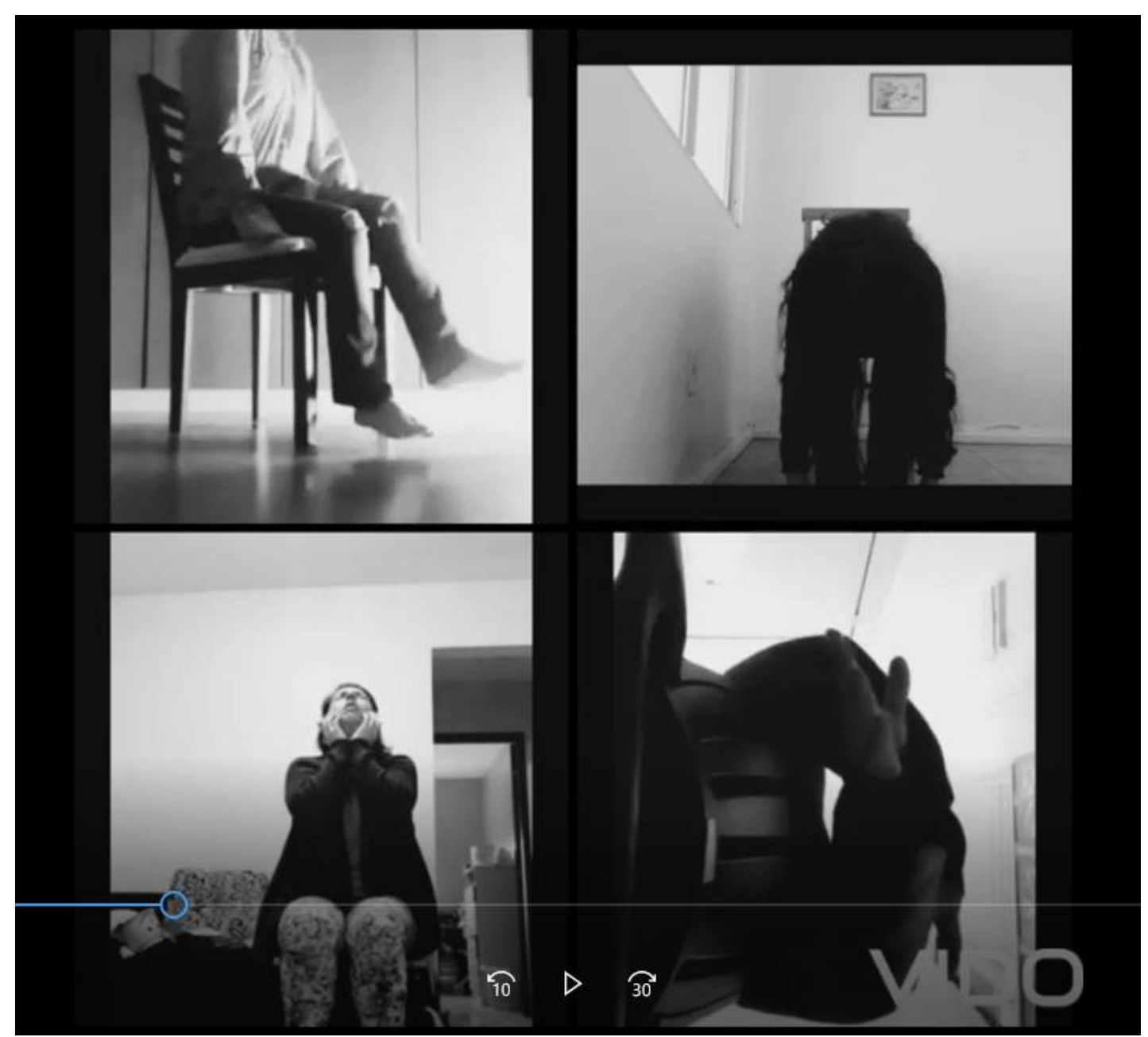

Fonte: Autores(as)

${ }^{13}$ In writing from this perspective of the body, the writer (or researcher) records in writing the subtle ways the body responds to experience and imbues his or her writing with the rich sensorial texture of that experience (Anderson, 2002, p. 41). (Tradução: Autores/as) 


\section{Urdimento}

Figura 7 - Reprodução de anotações de encontro de discussão do grupo

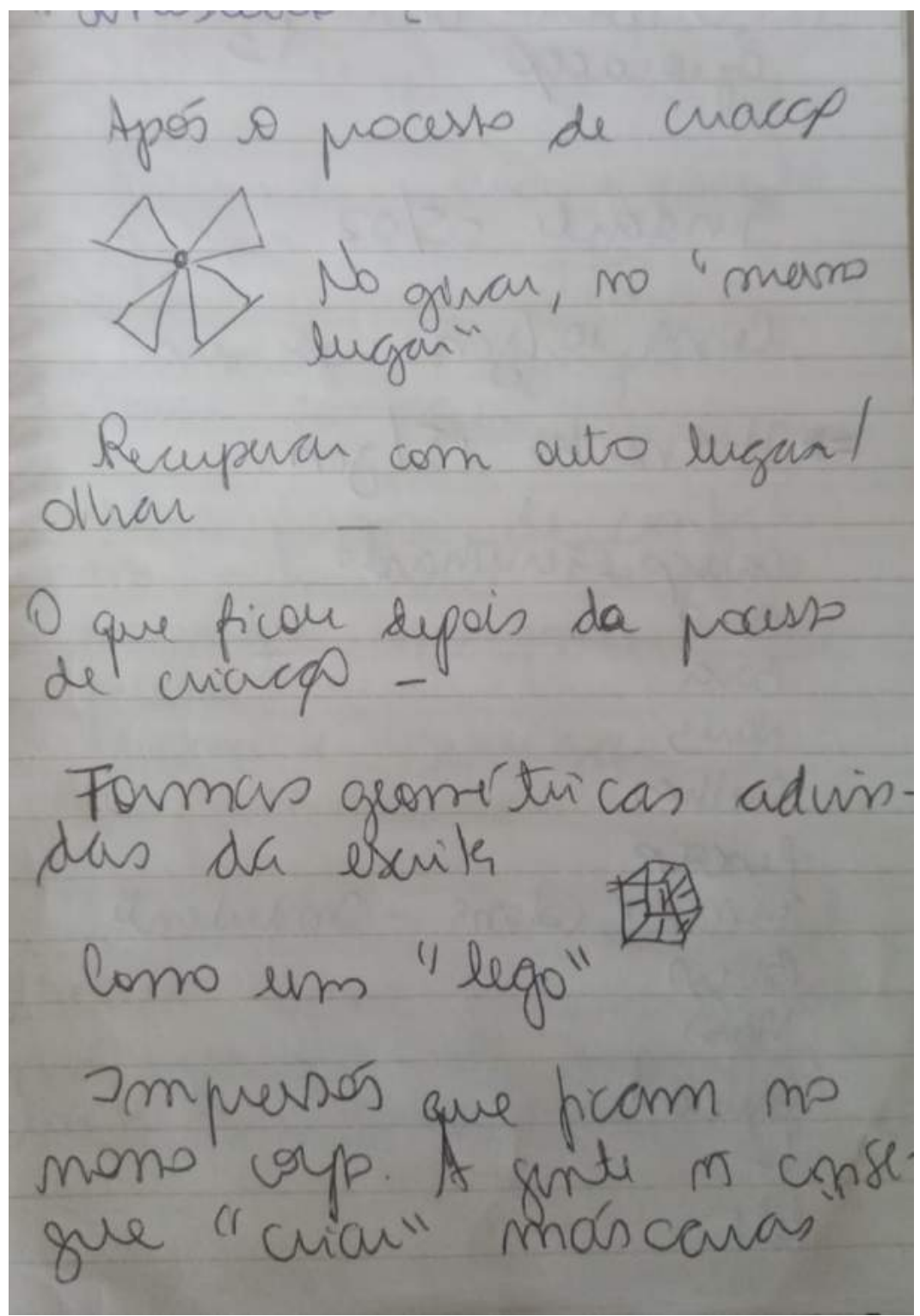

Fonte: Autores(as)

Um corpo, uma casa, uma experiência

Um sol adentra entre os vãos da casa, da janela, do teto. Um vento que toca suavemente na pele do corpo que somos. Uma coluna que sente o peso de um espaço-tempo suspenso, irremediável e inaudível, reverberando suas camadas, poeiras e peripécias de um organismo que precisa despertar. Pássaros, gatos, 
luminosidades, ambiências, tridimensionalidade e bidimensionalidade do virtual e real avistam um mundo em ruínas, onde a esperança já se desfez, líquida, por corpos em espera, corpos em enclausuramento, sedentos pela cura, pela salvação de dias melhores e de democracias melhores.

Uma sede de se aventurar em outros rumos do mundo deriva destes corpos, destas corporificações, destas escritasdançantes e destas esperas, afinal, como afirma Cristian Mossi (2017, p. 47) "não se sabe o que podem estes textos, assim como não se sabe o que podem todos os corpos." Somos seres em completa procura e busca - artistasdocentes ${ }^{14}$ investigando entre casas, corpos, poéticas e práticas as possíveis invenções e sobrevivências do dançarescrever em tempos de caos, morte e vida.

Casas cheias de espera, casas em confinamento, casas e corpos à beira da lou(cura), da inverdade, da irracionalidade do real. Casas e corpos que aderem, mas ao mesmo tempo-espaço expulsam suas dores, movimentos e retenções. Recobram na experiência, no corpo e nas suas travessias somáticas que o corpo só pode escrever-ler-pesquisar por aquilo que sente por si mesmo que o atravessa como único. Como diz Larrosa (2011, p. 11) “a formar ou transformar minha própria sensibilidade, a sentir por mim mesmo, na primeira pessoa, com minha própria sensibilidade, com meus próprios sentimentos." Por vezes, ao longo desses meses, este corpo-soma sofreu. Sofreu pela clausura, pelo medo da contaminação, pela incerteza da vida. Quanto tempo ficaremos em compasso de espera? É preciso ficar em compasso de espera? Quanto tempo ainda mais a presencialidade será adiada, quanto tempo ainda será um risco para a vida? Sobre isso, Flávia Naves (2016, p. 38) diz que:

É o filósofo francês David Lapoujade quem vai nos dizer em seu "O corpo que não aguenta mais" sobre a diferença entre a ferida grosseira e a sutil: da primeira devemos nos proteger, mas à segunda devemos nos abrir, pois que a potência de um corpo se mede pelo grau de exposição às feridas mais sutis: A potência do corpo (aquilo que ele pode) se mede pela sua exposição aos sofrimentos ou às feridas. Mas Nietzsche diz: as feridas são as mais sutis. Isto quer dizer que a exposição do corpo se faz

${ }^{14}$ Compreendemos que somos artistas e docentes ao mesmo tempo e que o hífen que separaria as duas profissões pode dar uma indicação dicotômica. 
no interior dos mecanismos de defesa... e que o protegem das feridas mais grosseiras. Sutil, aqui, não quer dizer leve ou benigno, mas ao contrário, quer dizer que as defesas operam suficientemente para que eu tenha acesso à profundeza e à violência de uma ferida sutil - ou, inversamente, que eu tenha acesso à sutileza que esconde uma ferida grosseira" (Lapoujade, 2002, p.87-88). ${ }^{15}$

Nossos corpos não aguentavam mais. Fomos mandados(as) de volta para nossas casas em março ${ }^{16}$. Em junho voltamos a nos encontrar, pelas telas. Seguíamos em casa. As saídas eram as mínimas necessárias: para receber a teleentrega, para ir ao supermercado ou farmácia. Estávamos todos(as) enclausurados(as) e, até ali, quase toda a comunidade ${ }^{17}$ em que vivemos. A vontade era sair, ver o mundo lá fora. Gritar. Nossos corpos não aguentavam mais. E a saída foi o reencontro, no entre-telas, pois:

Através da arte da performance é possível nos apropriarmos dos nossos corpos e das feridas que neles se inscrevem para então experimentar o surgimento da potência de um corpo performativo, corpo que vive o paradoxo: "de um lado, um 'Eu não aguento mais' (tudo aquilo de que devo me defender, daquilo que meu corpo sofre e me faz sofrer), do outro, um 'Eu sinto (no sentido de que nos abrimos a tudo aquilo que advém sob o regime do sutil) (Lapoujade, 2002, p.89 apud Naves, 2016, p. 40).

Percebemos uma anestesia presente nestes corpos e nestas casas que perpassa o lugar da experiência, do singular e do comum. Onde o saber-sentir ${ }^{18}$ se exaure, perde-se. A anestesia aparece na rotina já desgastada de pandemia numa camuflagem da experiência e da vida, numa categoria que nega o valor da vida,

15 Na citação de Naves há uma citação direta de Lapoujade (2002).

${ }^{16}$ Os(as) integrantes do Grupo de Pesquisa ficaram em isolamento social desde março de 2020, em trabalho remota. Alguns(as) tiveram que sair para trabalhar presencialmente em casos específicos, outros continuam em distanciamento, em home office.

${ }^{17}$ Aqui nos referimos à cidade de Santa Maria (RS). O governo do Estado do Rio Grande do Sul estabeleceu em 11 de maio Distanciamento Controlado, que prevê bandeiras mais ou menos restritivas, a partir de 11 indicadores de risco que são controlados semanalmente. A partir deste modelo, as atividades socioeconômicas começaram a ser retomadas gradativamente. A maior abertura socioeconômica ocorreu entre setembro e novembro.

18 Para Rudolf Laban, em meados da década de 1910, o primeiro dever do bailarino, como também do ator e do mímico, é desenvolver um "saber-sentir", mas este não diz respeito somente "aos fatores biológicos da vida”, mesmo que este aspecto seja fundamental. O afinamento da percepção deve também conectar o bailarino aos fluxos rítmicos da vida moderna, a suas vibrações (Suquet, 2008, p. 525). 
das pessoas, do arquivamento, do real e do verdadeiro. Ou até mesmo no descontrole e abuso de comidas, bebidas, roupas, consumo. Um corpo que grita para ser anestesiado, quase como uma categoria de juízo final: não queremos sentir.

Saber-sentir essas casas, corpos, experiências faz parte de um grito de socorro, de escuta, de lamento pelo que passou, pelo que passará e ainda para o que acontecerá como prelúdio ao futuro:

Corpos, palavras, números, imagens e sons emitem gritos profundos, alaridos constantes. Desenham um mundo em ruínas, uma humanidade perdida, uma natureza destruída e culturas ameaçadas. Em meio ao caos, palavras de ordem mobilizam cadeias de ação-reação: agir, re-agir, agir, re-agir. Conter o caos. Reter o caos. Eliminar o caos. Erguer um mundo no qual não podemos mais crer e, numa sintaxe desesperada, empreender fortes movimentos de coleta, identificação, codificação, recuperação, conservação e controle do que resta, do que está no limite do desaparecimento. Corpos identificáveis. Imagens legíveis. Palavras compreensíveis. Números exatos. Sons decodificáveis. Gritos...? Escuta? (Dias, 2012, p. 157).

Em tempos de espera, alguns sentidos são ampliados e outros por vezes reduzidos. Buscar uma harmonia entre sentidos seria o que muitos(as) gostaríamos, mas nem sempre isso acontece. Entre o caos e o ideal, nos reinventamos entre corpos dançantes sedentos por liberdade. Passamos a percorrer por entre espaços reduzidos, compreendendo como espaço tudo o que estava no nosso entorno. Quando passamos a conceber o principal espaço como sendo nossos próprios corpos, compreendemos que poderíamos percorrer por caminhos diversificados, mas com uma expansão interna de força e expressão capturados por uma tela de celular ou computador, que desnudava nossos espaços chamados lares. Mesmo que os objetivos fossem caminhar juntos(as), como pesquisadores(as), percebemos que nosso caminho era o retorno e a compreensão sobre si e sobre o que realmente nos limitava a movimentar nossos corpos. Medos, angústias, ansiedades, incertezas, enfim... fomos inundados(as) por sentimentos que poderiam ter bloqueado nossas potências. Entretanto, utilizamos todos estes sentimentos como disparadores para nos unirmos e encontrarmos 
caminhos sutis de conceber dança por outros espaços que não os que comumente estávamos acostumados a dançar. Então, dançamos para nós mesmos e, percebemos que aceitando nossas limitações conseguiríamos contar sobre nossos processos de pesquisa em dança em tempos de pandemia.

Ao descobrirmos que nossos principais espaços éramos nós mesmos, percebemos que alguns ruídos eram determinantes em nossos processos de criação e, quando elencamos determinados horários dos nossos dias como mais propensos à entrega aos processos criativos, contemplamos, através de uma escuta interna, que nossos corpos se adaptavam melhor em determinados horários por reduzir os ruídos externos que por vezes interferiam no processo da escuta de si, gerando ruídos conflitantes entre prestar atenção no seu próprio corpo e em tudo o que voltava nosso foco para algo externo. Aos poucos agregamos estes ruídos desconcertantes como aliados em nossas narrativas orais e escritas. As telas que capturavam os processos de criação aliaram-se aos processos de reconhecimento como se fosse um espelho que refletia todo e qualquer movimento que fazíamos. Corpos e telas envoltos por outros espaços que foram sendo adaptados a partir dos nossos próprios corpos, hoje criando identidades de pertencimento e de escuta de si e do outro.

Em meio a tantas tentativas de nos reinventarmos, nossos laboratórios de experimentação foram ganhando espaços que antes não nos permitíamos mas que hoje viraram potência de acolhimento. Como estaremos e o como retornaremos ainda não sabemos, o que estamos convictos é que percebemos que somos capazes de nos reinventar e potencializar nossos corpos dançantes em todo e qualquer tempo e espaço.

O que ainda poderemos sentir-saber após uma pandemia? O que estes corpos irão permitir ser, fazer, pesquisar nestes trânsitos intermináveis de uma antes - entre - pós covid-19? O que poderemos salvar dessas experiências de vida, morte, enclausuramento - sem, contudo, negligenciar ou anestesiar os corpos, as casas, as experiências e as subjetividades? Que remédios poderão curar um corpo incurável pelas experiências que viveu antes - entre - pós covid-19? 0 que poderá curar um corpo incurável pelas experiências que o singularizou? 
Muitas questões permanecem abertas, já que pedem passagem para que assim fiquem provocando aos corpos e às escutas, outros modos de seguir os trajetos da/em pesquisa. Nosso trabalho de escritoresdançantes (escritorasdançantes) faz-se neste espaço branco e vazio, onde colocamos estas experiências a friccionar seus modos de operar e ser. Lançando-nos à pesquisa e ao que dela deriva, um caos, uma ordem, um salvamento, destes trajetos vividos entre uma pandemia, sem esgotar ou preencher, mas documentá-la como uma cura daquilo que sobreviveu de cada corpo.

Nessas aberturas, só podemos supor que ao produzir criações, processos, produtos da arte e da educação entre um corpo, uma casa e suas experiências que ora são “singulares, próprias e únicas” (Larrosa, 2011), produz-se também afirm(ações) da vida, das marcas que ficarão para as histórias destes corpossujeitos, artistasdocentes, segundo Suely Rolnik (1993, p. 5) "as marcas são os estados vividos em nosso corpo no encontro com outros corpos, a diferença que nos arranca de nós mesmos e nos torna outro". Essa produção de diferença mostra-se em nossas grafias, gestos e corporeidades do vir a ser, seja na tela ou na dilação desse encontro virtual, produzindo um labor sobre a sobrevivência dos corpos e dos gestos, das práticas sensíveis e naquilo que elas podem salvar, manter e fornecer aos escritores-leitores(as) numa espiralada ação de escreverdançar. Na Figura (8) podemos re/ver/ler estes arquivos: 
Figura 8 - Reprodução de anotações de encontro de discussão do grupo

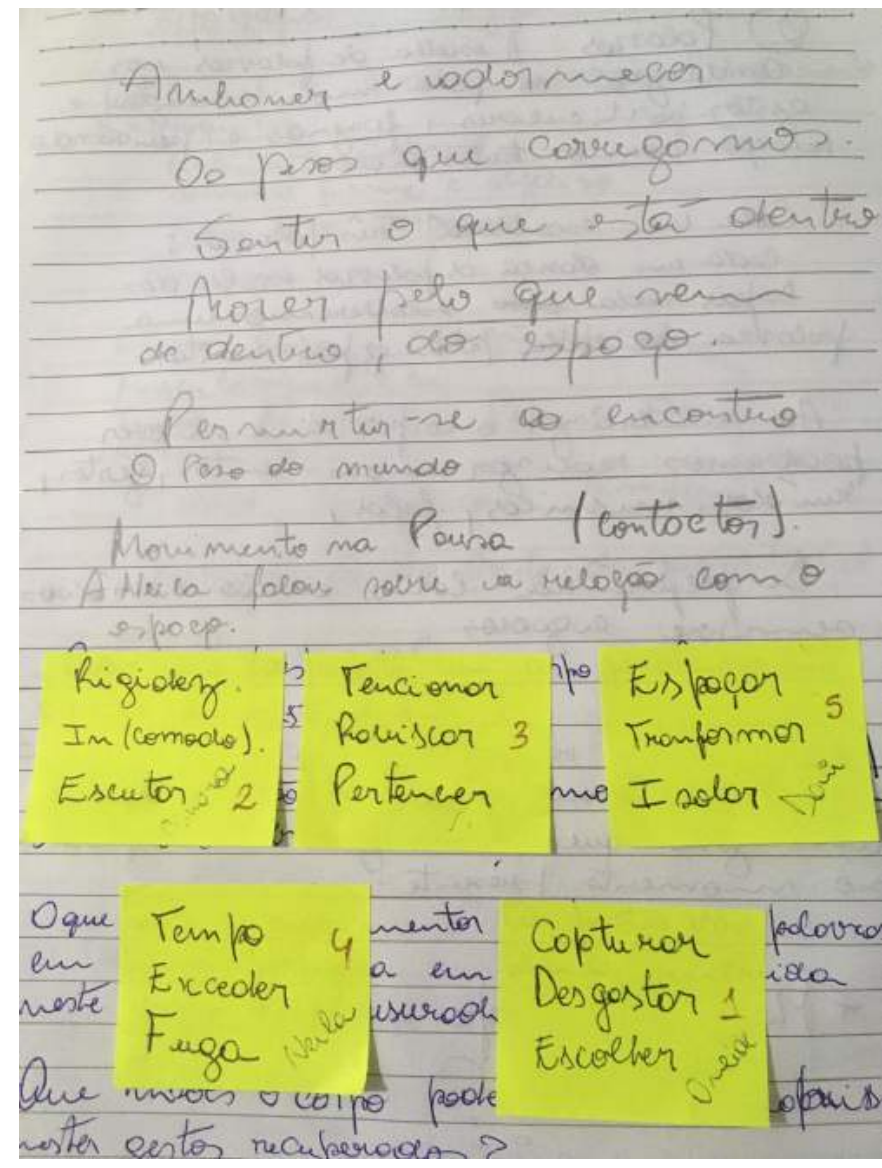

Fonte: Autores(as)

Mesmo o grupo laborando e inventando seus modos de operar, vimos que precisávamos dessa pausa necessária a tudo que vínhamos vivendo, assim essa pausa ocorreu como uma tentativa de burlar e fazer funcionar outros meios do pensamento, da racionalidade, do corpo e da sensibilidade humana. Isso diz respeito a outras formas de "contactos" (Lepecki, 2020) que na atualidade precisam se atualizar. Onde os humanos que ora operam máquinas e por elas também são operados, necessitam de meios digitais, escriturais, imagéticos, audiovisuais para se comunicar, falar, dançar, escrever. Entretanto, é emergente o que vivemos agora, nesta pausa de existência, onde as práticas artísticas e pedagógicas em sua ampliação poética são curadas, escritas, refletidas e lançadas ao mundo, conduzindo o corpo e a história uma marca daquilo que ficará como proposta, produto e processo deste tempo de espera, caos, morte e guerra. 
Por fim, a partir destas marcas, subjetividades e experiências escrevemos que:

Temos juntado dores, de um corpo engessado pelo tempo-espaço pandêmico. Um corpo que a cada dia se ausenta de sentir e criar, como se o mundo como o conhecemos já não existe mais.

Temos aglomerado em tempos de não aglomeração fadigas musculares, não do excesso de dançar e compor, mas das exaustivas jornadas de trabalho sentado, em frente a uma tela que agora é o mundo.

Temos arquivado sensações de andar na rua e sentir o vento que toca a pele, o rosto, as palmas da mão. Onde nossa cinesfera corporal ganha intensidades infinitas de tamanho e proporção. Onde o corpo não se esquiva, mas tenta agrupar.

Nestes liminares, podemos dizer que a pesquisa e seus arquivamentos tanto escriturais, imagéticos, corpográficos e ensaísticos compõe travessias dialéticas entre um corpo que tenta sobreviver ao caos e aos afectos.

\section{Considerações finais}

Nossa anestesia inicial foi se dissipando à medida em que nos encontrávamos no entre-telas e à medida em que realizávamos nossas práticas sensíveis e refletíamos sobre elas. Percebemos que, neste contexto pandêmico em que nos encontramos, a cura não é da Covid-19 - pela qual os(as) cientistas e médicos(as) buscam incessantemente - mas a de todo o contexto. Vivemos um trabalho de cura de nós mesmos, do que a pandemia nos provocava, e, a partir das práticas sensíveis, do trabalho coletivo, em grupo, fomos encontramos modos de (sobre)viver (a) este momento. Terra (2011, p. 168) nos lembra que "[...] a sensibilidade pode ser aprendida, desenvolvida, trabalhada, educada, pois não é algo inato nem restrito ao sujeito. Apesar de sua profunda dimensão subjetiva, consiste em um fenômeno cultural, social e histórico." E que o desafio, para o artista da cena, é tornar a sensibilidade sensível a si, ou seja, saber-sentir. Percebemos, ao longo desta longa pandemia, que tivemos que (re)aprender a saber-sentir - porque por vezes sentíamos demais o que estava ao nosso redor e nos anestesiávamos de tanto sentir, de tanto absorver o momento pandêmico - e que as abordagens somáticas nos possibilitaram esta reconexão com os nossos 
sentires, conosco, como o mundo, ao mesmo tempo em que nos permitiram (sobre)viver ao caos pandêmico.

Não temos dimensão, hoje, do valor estético ou artístico da obra-experimento realizada, muito menos temos como valorar as investigações que realizamos e não gravamos. Mas temos dimensão da potência desta busca e de quanto ela nos permitiu hoje estarmos aqui escrevendodançando nossas dores, amores, medos, angústias e felicidades. Sim, porque tivemos todos e todas de nos reinventar, não apenas artistas, e, com isso, buscar instantes de felicidade para sobreviver ao caos. Compreendemos, a partir de Cunha (2016, p. 232) que:

De acordo com Rancière, na expressão partilha do sensível estaria contida "a chave da junção necessária das práticas estéticas e práticas políticas” (Rancière, 2005, p. 15) para que se possa definir um contorno possível do que seja o comum partilhado numa abordagem crítica e política. Na partilha do sensível se estabelece a divisão: [...] dos espaços, dos tempos e tipos de atividades que determinam propriamente a maneira como um comum se presta à participação e como uns e outros tomam parte nesta partilha. [...] (Rancière, 2005, p.15-16) ${ }^{19}$.

Compreendemos que, estarmos juntos(as), no entre-telas, neste momento pandêmico, em um país desgovernado e irrespirável, conseguimos não apenas sobreviver, mas também, como afirmam Rachel, Marques e Mariano (2020, p. 20) respirarmos coletivamente, uma vez que:

Para o filósofo italiano Franco Berardi, é precisamente a partir da respiração de cada corpo que estabelecemos uma certa correspiração que permite respirarmos juntos uns com os outros (Berardi, 2020), seja em um determinado grupo, em uma dada coletividade ou, se preferirmos, de algo que também poderia ser chamado de comunidade, como a supracitada comunidade escolar.

Este momento pandêmico ainda irá perdurar por muito tempo, mesmo depois da vacina, mesmo depois de encontrada a cura, pois ficará nas nossas corpografias. E, num ato de resistência/(re)existência ao que vivemos, sobretudo neste país - pois em outros, o modo como a pandemia foi encarada foi diferenciada, sabemos que é preciso pausar para se refazer - a ação-recuperação

${ }^{19}$ Na citação de Cunha (2016) há citação direta de Rancière (2005). 
de Laban - mas também é preciso se mover para se curar. Seguiremos nos movendo e nos comovendo.

Nossas escritasdançantes e nossas corpografias contidas neste documento fazem parte, portanto, de uma tentativa de salvamento desses corpos que ora sobreviveram ao que passou de uma pandemia. Mesmo assim, esse trabalho de práticas somáticas - e que se apresentou a nós como sensíveis - colaborou para explorar cada vez mais o caráter emergente das artes cênicas a partir de práticas performativas, pedagógicas, inventivas e poéticas, problematizadas a partir de diferentes liminares conceituais e estéticos, onde recusam um receituário do fazer, mas o inventam a cada nossa investigação. Assim, reorganizam os devires do fazer, pensar, pesquisar em arte e nas suas diferentes manifestações dos corpos, das escritas e dos arranjos estéticos e políticos de fazer brotar uma investigação em meio ao digital, ao remoto, ao isolamento, à casa, à intimidade e à reinvenção do(a) artistadocente.

A cura que procuramos e tateamos nestas travessias vai além de um remédio parasitário que mantém a doença no organismo. Nossas práticas foram colocadas como curativas de feridas que foram expostas e abertas pelo caos de uma doença que até então mostrou solidariedade e compaixão, mas também visibilizou o grande abismo existente entre pessoas, renda, consumo, educação, arte e tantas outras formas de vida. Disso, só podemos curar aquilo que mais valora nossas pesquisas e processos, o de manter o ético-estético-político sempre renovado e vivo, confrontando falsas moralidades e curas milagrosas de um corpo que sempre precisará aprender saber-sentir o sensível, poético, real e vivo.

\section{Referências}

ANDERSON, Rosemarie. Embodied writing: Presencing the body in somatic research, Part I, What is embodied writing? Somatics, Novato, v.8, n.4, p. 40-44, spring/summer, 2002.

ARAÚJO, Márcia Feijó de. Corpo e dança: Angel Vianna e a manutenção da sensibilidade. Revista Interinstitucional Artes de Educar. Rio de Janeiro, V. 6, N.1- 
p. 406-415 jan.-abr. 2020: "Educação: Corpo em movimento II." Disponível em: https://www.e-publicacoes.uerj.br/index.php/riae/article/view/45870. Acesso: em 4 nov. 2020

BARBOSA, Vivian Vieira Peçanha. Laban e Merleau-Ponty: Relações entre teorias de corpo, movimento e percepção. Revista Moringa - Artes do Espetáculo, João Pessoa, v. 7 n. 1, jan./jun., p. 97 a 117, 2016.

CALVINO, ítalo. As cidades invisíveis. São Paulo: Cia das Letras, 1990.

CUNHA, Adriana Miranda da. Mapeando o Corpo: proposições práticas para a partilha do sensível nas representações do corpo em criação, Urdimento, Florianópolis, v.2, n.27, p.228-240, 2016. Disponível:

https://www.revistas.udesc.br/index.php/urdimento/article/view/8733> Acesso em : 11 jan. 2020.

DIAS, Suzana. Escuta Inumana. murmúrios de uma vida irrepresentável pelo grito arquivista... Leitura: Teoria \& Prática, Campinas, v.32, n.62, p. 155-167, jun. 2014.

FERNANDES, Ciane. Em busca da escrita com dança: algumas abordagens metodológicas de pesquisa com prática artística. Dança, Salvador, v. 2, n. 2, p. 1836, jul./dez. 2013.

FERNANDES, Ciane. Pausa, Presença, Público: da DançaTeatro à PerformanceOficina. Revista Brasileira Estudos da Presença, Porto Alegre, v.1, n.1, p. 77-106, jan./jun., 2011.

FREIRE, Paulo. Pedagogia da Autonomia: saberes necessários à prática educativa. São Paulo: Paz e Terra, 1996.

HANNA, Thomas. The somatic healers and the somatic educator. SOMATICS. Magazine Journal of the Bodily Arts and Sciences, Volume I, No. 3, Autumn 1977. Acesso em: 02 fev. 2014.

LARROSA, Jorge. Experiência e alteridade em educação. Revista Reflexão e Ação. Santa Cruz do Sul: UNISC, 2011. p. 04-27.

LARROSA, Jorge. Pedagogia profana: danças, piruetas e mascaradas. 4. ed. Belo Horizonte: Autêntica, 2006

LABAN, Rudolf. Domínio do movimento. São Paulo: Summus editorial, 1978.

LEPECKI, André. O Movimento na Pausa. ConTactos, 2020. Disponível em https://contactos.hemi.press/movimento-na-pausa/?lang=pt-br. Acesso em: 12 out.2020.

LISPECTOR, Clarice. Água Viva. 9ạ Ed. Rio de Janeiro: Nova Fronteira, 1980.

LISPECTOR, Clarice. A paixão segundo G. H. 4 ed. Rio de Janeiro: Livraria José 
Olympio Editora, 1974.

MONTENEGRO, Oswaldo. Me ensina a escrever. 2014. Disponível em: < https://www.youtube.com/watch?V=B2GW-2FWZVU>, Acesso em: 28 dez. 2020

MOSSI, Cristian. Um corpo-sem-orgãos, sobrejustaposições: quem a pesquisa [em educação] pensa que é. Santa Maria: Ed. da UFSM, 2017.

MILLER, Jussara; LASZLO, Cora Miller. Corpos em conexão, corpos em presença. Manzuá - Revista de Pesquisa em Artes Cênicas, v. 3, n. 2, p. 95-116, 24 nov. 2020.

NAVES, Flávia. Carta à performer Eleonora Fabião: o que pode um corpo que sofre. Urdimento, Florianópolis, v. 2, n. 27, p. 36-45, 2016.

NICOLELIS, Miguel. Máquina de criar universos. [Entrevista concedida a]. Guiliana Bergamo. Ecoa. São Paulo, 2020. Disponível em: https://www.uol.com.br/ecoa/reportagens-especiais/miguel-nicolelis-nossaforma-de-aprender-e-por-meio-do-contato-social/\#cover Acesso em: 17 dez. 2020

PÉREZ, Carmen Lúcia Vidal. SAMPAIO, Carmen Sanches. Conversas sobre aprenderensinar a ler a escrever: (nos) alfabetizando com crianças e sem cartilhas... In: LIBÂNEO, José Carlos. ALVES, Nilda (org.). Temas de Pedagogia: diálogos entre didática e currículo. São Paulo: Cortez, 2012. p.395-429.

RACHEL, Denise Pereira; MARQUES, Diego Alves; MARIANO, Bárbara Kanashiro. Artivismo respiratório: Uma Proposta de Educação Remota no país irrespirável. Revista Manzuá, Natal, v. 3, n. 2, p.7-34, 2020. Disponível em: <https://periodicos.ufrn.br/manzua/article/view/22725> Acesso em: 1 dez. 2020

RIBETTO, Anelice. Experiência, experimentações e restos na escrita acadêmica. In: CALLAI, C.; RIBETTO, A.(Org.). Uma escrita acadêmica outra: ensaios, experiências e invenções. Rio de Janeiro: Lamparina, 2016

RIBETTO, Anelice. Experimentar a pesquisa em educação e ensaiar a sua escrita. 2009. Tese (Doutorado em Educação) - Centro de Estudos Sociais Aplicados, Universidade Federal Fluminense, 2009.

ROLNIK, Suely. Pensamento, corpo e devir - Uma perspectiva ético/estético/política no trabalho acadêmico. Cadernos de Subjetividade, v.1 n. 2: 241-251. Núcleo de Estudos e Pesquisas da Subjetividade, Programa de Estudos Pós Graduados de Psicologia Clínica, PUC/SP. São Paulo, set./fev. 1993. Disponível em: http://www4.pucsp.br/nucleodesubjetividade/Textos/SUELY/pensamentocor podevir.pdf

SUQUET, Annie. Cenas. O corpo dançante: um laboratório da percepção. In: COURTINE, Jean-Jacques (Org.). História do corpo: as mutações do olhar. O século 
XX. Petrópolis: Vozes, 2008. v. 3. p. 509-539

TERRA, Ana. Saberes sensiveis no trânsito somático-dançante. In: WOSNIAK, Cristiane; MARINHO, Nirvana (Org.). Seminários de Dança. O Avesso do Avesso do Corpo Educação Somática como práxis. Joinville: Nova Letra, 2011, p. 163-183.

VIEIRA, Marcilio de Souza. Coreologia: habitações poéticas da obra labaniana, Urdimento, Florianópolis, v.2, n.29, p. 44-58, 2017. Disponível em: https://www.revistas.udesc.br/index.php/urdimento/article/view/141457310229201 7044 Acesso em: 06 jan. 2020

Recebido em: 15/01/2021

Aprovado em: 19/04/2021 